\title{
ASIAN MODERNISMS
}

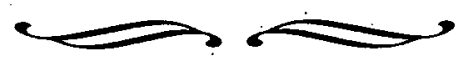

I. LOCATION:

At the end of the rggos it is relatively facile-for someone in Euramerica ${ }^{1}$ - to consider that various kinds of modern art work and artist from the non-Euramerican world have been accepted within it or have begun to be so. This seems to be particularly the case for Asian artists who have been seen at Les Magiciens de la Terre, ${ }^{2}$ at the Venice and São Paulo Biennales, and who are increasingly the subject of country ${ }^{3}$ or area-specific 4 shows or the major component of others. ${ }^{5}$ Such acceptance might also be taken to mean the incorporation of modern Asian art into the bounding intellectual paradigms of modernity and its histories which were supposedly invented in Euramerica: the position of the centre may have moved, but it is still the centre.

This essay does not accept either of these premises: Other positions can be briefly but directly brought into focus if we consider two Asian artists of Indian origin and the intellectual constructions around them. Anish Kapoor is an artist of Indian origin residing in London, who has been exhibited at the Venice Biennale in the British pavilion and is the subject of 'major' critical overviews by leading Euramerican curators and critics. ${ }^{6}$ N. N . Rimzon is an Indian artist residing in India who has been exhibited abroad but who has not been the subject of such a Euramerican catalogue. 7 The one is subject to Euramerican discourses which privilege themselves by the incorporation of difference. The other is subject to no such Euramerican gaze but remains, however formally, cognate and qualitatively related to the work accepted in Euramerica, as 'Indian' or in another discourse. Yet the latter has been seen in other sites outside both India and Euramerica, in for example Australia. This differentiation is between a vertical, unicentral model of art assimilation to Euramerican canons, and a horizontal, polycentral discourse between differently constituted centres, none of which claim to assimilate, nor indeed reconstitute, a . canon.

The difference of position derives ultimately from Euramerica's claim to have invented, and therefore to retain purchase on, modernity. This claim, whilst true in a rather simplistic developmental history, disappears the moment it is accepted that modernity invents itself everywhere it is required for a new relativization of the pasts of any given culture or group of cultures. The principal condition is that these cultures need toand are capable of-carrying out this relativization. It is a relatively easy step from this position to the future-oriented, 
projective relativization of modernism, or, further, to the involuted and eclectic rerelativization of modernity itself some call post-modernism. In the quite precise language of fashion and the street it is also called 'retro'. ${ }^{8}$ Seen this way modernity belongs to Asian artists because they work in societies and cultural discourses which require it. Modernity does not operate by the privilege of transfer from Euramerica or by the valuation of Asian modern art works and artists through their being accepted in Euramerica. Even before we approach the phenomenon of globalization, it is sensible to see how basic this difference of approach to modernity must be to one which privileges Euramerican origin.

\section{AFFILIATION}

But if modernity belongs to Asian art cultures because of their own demands, what kind of modernity is it? How did it come into being? How is it to be recognized from inside any particular Asian art culture or from without? If modernity is not owned by 'The West', does that mean the kinds of modernity found in, say, some Asian art cultures are different, new, or radically other?

The affiliation of such modernity may be constructed in at least three ways, the full implications of which are yet to be explored. One is to see it as contestatory, as in a dialectical relation to that which has occasioned or imposed modernity, "The West'. This is the colonial / post-colonial dimension of modernity, where modernity arises as a trajectory of subaltern counterappropriation or rejection and revolt. It implies, at least theoretically, a lack of authenticity or own demand driving Asian modernity because external stimulus is a necessary cause.

A second affiliation is to group modernities in a family of species which have derived from an $u r$-species. This is a model of affiliation where the branchings of a tree are seen to derive from common ancestors whose different sub-branchings represent (in a Darwinian evolutionary model of development ${ }^{9}$ ) the adaptations of the species to different conditions in different localities. A variant of this model is to accept the notion of species branching but to see these (in Gould's revisions ${ }^{\text {10}}$ ) as not in an hierarchical tree but in various bunchings of variation from the same original set of species which exist in parallel and not in a single hierarchy.

A third model of affiliation is to see modernity in art along the lines of different languages in dialogue under conditions of heteroglossia (as in Bakhtin ${ }^{\mathrm{I}}$ ). The dialogistic relation of such art discourses, that is their perpetual mutual relativization, may be interpreted as a fundamental condition of modernity. Affiliation is given because of common relativization, however it is achieved. Relativization can operate through the modes provided by colonial domination (India), internal self-development (Japan), 
and various kinds of quasi-sovereignty which seek to maintain the unitary identity of discourses even as they are broken down by contact from without (China).

In art history it has been relatively easy to overlook the different implications of these models of affiliation, because of the transfer of styles and their ideological constructs from 'The.West' to Asia. The transfer and overlaying of technical and symbolic values has taken attention away from the meaning of these transfers from within, and from the way authenticity has been created for a wholly new and constructed 'tradition' at this interface.

'Tradition' has often been hermeneutically opposed to 'modernity' when the 'traditional' has only been made possible by the 'modern'. But even as the 'modern' has been relativized by its transfer from 'The West', so the neo-traditional has been secondarily relativized by its constructed discursial difference from the 'modern'. Thus have modern Asian art discourses been constructed not along the lines of single 'East/West' split but at least by the process of primary and then secondary relativization-which I choose to call 'double othering'. ${ }^{12}$ This process can act as a relativization or 'othering' ${ }^{13}$ between a distancing of the neo-traditional Kannon the Compassionate Mother by Kano Hôgai, I888, from its 'Japanese' pasts, and further by its separation from the position of nearcontemporary 'Western-style' work like Kannon riding on a Dragon, by Harada Naojirô, 1890 .
3. HISTORIES:

Relativization of the past may be the historical position of modernity whose marker is the caesura in local discourses created by the wholescale transfer of 'Western' academy realism. Such a position has tended in the discourse of interpretation to render the onset of modernity as a radically historical disjunction. But on closer examination of the historical record in the discourse of art works ${ }^{14}$ it may easily be seen that modernity in several Asian art cultures such as Japan or India did not start with the transfer of 'Western' realism, and indeed had a long antecedence in many proto-modern features of art discourses and in the structures of the art world. One cannot also ignore the longevity of the linkages between the pre-histories of modernity in Asia and Euramerica. There is thus neither a caesura in cultural relations nor an absolute rupture in the way art discourses are related to their pasts. It seems that part of the reason why there is a tendency to create such interpretive caesura is a reflection or reduplication of the levels of binary structures habitual to the Euramerican world, such as imperial/metropolitan and colonial/local. This world has not been noted for its creation of discursial spaces defined between multiple centres and histories.

Furthermore, what one might call the habitual Euramerican interpretive mode has tended to see the inward movement of academy realism in a linear series of stages 
such as transfer, assimilation, and transformation. This view has concealed or de-privileged the various kinds of relativization implicit in such processes for an Asian art world. It has concealed how many features of modern and modernist modes of art discursial change were present inside these transfers. Perhaps the largest shift in art historical interpretation required for art history by modern Asian art is one away from the notion of transfer marked by the dissemination of models of stylistic development. Interpretation, whether exogenous or endogenous to any art discourse, should move to understanding a range of processes of relativization as imbricated within the complex term modernity / modernism / post-modernism. In this complex, any particular stylistic model or congruence is probably the least signifying element for the endogenous art discourses involved. The discursial space has to be left for a kind of co-option by local movements of an international one, and I would argue this is often found even very early in the transfer of realism. The co-option is not principally of the local by the central which would be the habitual (and still colonial) perspective. Such a position also possibly accounts for the perverse late-or post-modernist pleasures to be derived both endogenously and exogenously from I99os' Chinese 'popism' such as in the work of Zhang Xiaogang, a discourse which cynically manipulates a surface conventionality in order to sequester-I would argue - - a subversive parody safely within. ${ }^{15}$

\section{NATIONS}

For most Asian cultural discourses the modern began with the relativization of the past provided by the historical break of colonial or neo-colonial rule. As importantly it also began by the reaction against this in the form of an anti-colonial movement, and independence struggle towards the founding of a new state. However hegemonic the new state became in claiming domain over many kinds of society and cultural discourse within it, such states claimed to have founded the nation, to have integrated many discourses under its umbrella, and in most cases to have provided the leader of the people. The modernist striving for a desired future articulated between a leader and a people became a frequent subject for pictorial representation. This has historically been so much the case that one might postulate the thematic of modern Asian art to have been the allegorizing of the new nation through representing the new leader, and often of the very people who supported him. There is no doubt that as these male figures seek to articulate the masculinist privilege of serving the nation, ${ }^{16}$ so alongside them the female figure of the mother, or of multiple types of women as a repository of a variety of national values, or of a leader of the masses in the selfsacrificing figure of a toiling intellectual, acts as a feminising counterpart, ${ }^{17}$ even if this counter allegory can only rarely be described as feminist in intention.

Two conditions seem to have changed the possibility for this type of national 
allegory. One is the success of the movements under or against colonialism, where nationalism survived as a strategy for creating a repertory of ideal figures in a national imaginary under the conditions of a rapidly de-colonizing world. This can provide a kind of semantic exhaustion where the use and re-use of a particular metaphor, like Chairman Mao as Great Helmsman, turns into a saturated metonym, a kind of image coinage where value - or metaphorical weight-resides in the currency system not in any particular image. A second, and usually consecutive, condition is found where the colonial or the reaction against it only survives as a dim echo in a national imaginary now preoccupied with negotiating the post-colonial terms of its relation to a globalizing world. Thus stand the agonized, repeated faces of Philippine peasants in works by Alvorado Nunelucio looking out in the individualized frames of their images. ${ }^{18}$ Through the slightly hallucinatory effect of their black outlines and primary colours they flicker, in a way like alternative TV pictures, to subvert the very fractionating forces which place them in a world economy and split them off from their former lateral solidarity in the possibility of a Philippine 'nation'.

\section{MEDIATORS}

Art history, at least any art history of modern art, cannot at least escape the possibility it will serve as a cultural critique, even if it is not explicitly. so intended. Any exogenous or endogenous construction of a modern, modernist, post-modernist or simply contemporary art in Asia is going to privilege some kinds of art against others. But in a world brought into close communication within and between art cultures, the figures who have normally provided for these kinds of assessment in various functional domains-critics, curators, journalists, art historians - with modern art are always serving to re-position the 'new'.

The endogenous role of a critic, curator, or dealer in mediating and sometimes forming a group of conceptual perspectives around a cohort of disparately arranged artists is well known in Euramerica. It has also been a significant feature of Asian modernity, such as the role played at different times by Geeta Kapur in India, ${ }^{19}$ Li Xianting in China $^{20}$ or Nakahara Yûsuke in Japan. ${ }^{21}$ The important feature of such critics, however well informed they may be about international and exogenous art movements or by their own personal experience, is that they work from inside a set of cultural discourses which are their own centre. But the late twentieth century has seen the advent of more specifically 'interface' critics, curators, and dealers who mediate supposedly scarce knowledge and works from the endogenous to the exogenous levels. There is no doubt this particular position has played a significant role in the mediation of particularly East Asian art cultures to international art exhibitions, and here the role of Nanjô Fumio ${ }^{22}$ and 
recently of Hou Hanru in China is prominent. ${ }^{23}$ Whilst there can be no doubt such mediators, or 'doorkeepers ${ }^{24}$ play an important role in inserting different types of Asian art into Euramerican discourses which otherwise might ignore them, they also manifest a minority opinion or a selective representation against the very complexity of the endogenous discourses they purport to represent to the exogenous. In other words, for an art history of modernity which includes Asia as one range of non-Euramerican practices it would be fallacious to assume this could wholly or even partially be based on the art introduced from such mediators to the international level, even under a shifting rubric of 'contemporary practice'. ${ }^{25}$ The hard but rewarding work of looking from inside at each endogenous discourse is the base for such an art history of other modernities, not the post facto hypothesizing of such a history from such works as have been articulated on exogenous levels.

Some will argue that the global, exogenous level of practice, of the distribution of works and of the career-cycling of artists has long ago penetrated down to the local endogenous level. This is an unexceptional objection. Many artists, some the most rooted in their endogenous discourses such as Rabindranath Tagore, have continuously paid attention to international levels, even as these were earlier structured by the very world colonialism they were trying to see a way for their cultures to escape from. If the modern involves relativization of the past, and modernism the elevation to the plane of a formal subjectivity of an orientation to different futures, and if we were to attribute hermeneutic sovereignty to the global level, then that relativization would disappear or become a mere simulacrous imitation of itself. This would be to reproduce - even from a supposedly progressive position-the structure of central super-ordination over the localnow abstracted onto a 'global' level-which the rich variety of practice made possible by modernism had the potential to resist, subvert, or at least circumvent. Whatever we conclude to be the role of globalizing forces in the late twentieth century, an Asian history of modern art would first have to construct what conceptually and pragmatically links its own discourses. $\propto$

JOHN CLARK

John Clark teaches in Art History and Asian Studies at the University of Sydney and recently published 'Modern Asian Art'.

This article will appear in the History of the Scientific and Cultural Achievements of Humanity (UNESCO/Routledge, forthcoming, 200o), edited by Caroline Jones.

\section{NOTES}

'This terminology, although perhaps unfamiliar, is necessary. Once the nontechnological cultural products of 'The West' were adopted, adapted, and transformed outside 'The West' the location of their geographical origin no longer constituted a 
privileged civilizational autonomy. One pernicious legacy of direct colonialism is that the cultural products transferred to the world from 'The West' are somehow always to be denied their authenticity to those who adopted them under its duress in places not in 'The West', at least seen from the position which I shall now locate in Euramerica or characterize as Euramerican. For fuller exemplification, see myModernAsian Art (Sydney: Craftsman House \& Honolulu: University of Hawaii Press, 1998).

${ }^{2}$ Jean-Hubert Martin (ed. \& curator), Les magiciens de la terre (Paris: Centre Georges Pompidou, 1989 ).

${ }^{3}$ One example is Gao Minglu (ed.) Inside Out, New Chinese Art (Berkeley:University of California Press, 1998).

4 Poshyananda, Apinan et al., Traditions / Tensions: Contemporary art in Asia (New York: Asia Society Galleries \& Sydney: The Fine Arts Press, 1996).

5 Hou Hanru and Hans Ulrich Olbrich, Cities on the Move (Ostfildern-Ruit: Verlag Gerd Hatje, 1997).

${ }^{6}$ Homi K. Bhabha and Pier Luigi Tazzi, Anish Kapoor (London: Hayward Gallery \& Berkeley: University of California Press, 1998); Germano Celant, Anish Kapoor (London: Thames \& Hudson, r996). That by Celant barely refers to Kapoor's Indian origins.

${ }^{7}$ For early Rimzon material see A. Dube, catalogue essay for Seven Young Sculptors (New Delhi: Kasauli Art Centre, ${ }^{9} 8_{5}$ ). See also Victoria Lynn, 'The art of N.N. Rimzon', Art \&Asia Pacific, 3, 2 (1996).

${ }^{8}$ Art historically speaking, modernity, modernism, and postmodernism do not form a series of clear-cut tripartite stages, but tend to overlap, particularly if there is a relative freedom to eclectically modify styles whose sources do not yet operate a bounding hegemony, such as the 'syncretic' architecture of early Meiji Japan.

${ }^{9}$ Darwin's position was as follows: 'Thus modern forms ought, on the theory of natural selection, to stand higher than ancient forms. Is this the case? It seems that this answer must be admitted as true, though difficult of proof', in Charles Darwin, The Illustrated Origin of Species, (abridged and introduced by Richard Leakey from sixth edition of $18_{7}$ including comments which update Darwin's theories or his evidence, London: Faber \& Faber, 1979), p. 174.

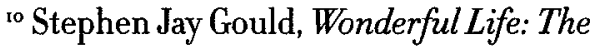
Burgess Shale and the Nature of History (London: Penguin Books, 1989), p. 47, "The maximum range of anatomical possibilities arises with the first rush of diversification. Later history is a tale of restriction, as most of these early experiments succumb and life settles down to generating endless variants upon a few surviving models'.

"I Since it seems so directly indicative of the problems raised here, please allow a somewhat lengthy citation from Bakhtin's 'Discourse in the Novel', found in M.M. Bakhtin, The Dialogic Imagination, (tr. C. Emerson, \& M. Holquist, Austin: University of Texas Press, I98I), pp. 284-85: 'But internal dialogization can become such a crucial force for creating form only where individual differences and contradictions are enriched by social heteroglossia, where dialogic reverberations do not sound in the semantic heights of the discourse (as happens in rhetorical genres) but penetrate the deep strata of discourse, dialogize language itself and the world view a particular language has...., my italics.

${ }^{12}$ For a discussion of this term, see my 'Yôga in Japan: Model or Exception? Modernity in Japanese art, 185os-1940s: An international 
comparison', Art History, I8.2, (June 1995), pp. $253^{-8} 5$.

${ }^{13}$ On 'othering', see my 'Gendai Ajia no Bijutsu gensetsu ni okeru "Taka" [Othering in Modern Asian Art discourses]', translated into Japanese in a volume edited by Shimamoto Kan, to appear in 1999 from a Tezukayama Gakuin workshop paper of 1996 .

${ }_{14}$ Modern Asian Art, Chapter Two on 'Prehistories'.

${ }^{15}$ See my 'Histories in the Modern', in Graeme Murray, Meg Syme and June Knight (eds), Reckoning with the Past: Contemporary Chinese painting (Edinburgh: Fruitmarket Gallery, 1996), Pp. 17-20.

${ }^{16}$ See the discussion of 'Chairman Mao goes to Anyuan,' in Julia Andrews, Painters and Politics in the People's Republic of China: r949-1979 (Berkeley: University of California Press, 1994), pp. 338-42.

${ }^{17}$ For a feminist understanding of Ravi Varma see Geeta Kapur, 'Ravi Varma's Unframed Allegory' in R.C. Sharma (ed.), Raja Ravi Varma: New perspectives (New Delhi: National Museum, 1993).

${ }^{8}$ Alvorado Nunelucio's work 'Duta Indi Bala' [Land not bullets] is reproduced in the catalogue of the FirstAsia-Pacific Biennale (Brisbane: Queensland Art Gallery, 1993), p. $3^{1 .}$

${ }^{19}$ Among Geeta Kapur's important earlier writings are Pictorial Space: A point of view on contemporary Indian art (New Delhi: Lalit Kala Akademi, 1977), Contemporary Indian Artists (Souza, Kumar, Padamsee, Husain, Khakhar, Swaminathan; New Delhi: Vikas Publishing House, I978); and Place for People, (text for exhibition, Jehangir Art Gallery, Bombay; New Delhi: Rabindra Bhavan, $\mathrm{I} 98 \mathrm{I}$ ).
${ }^{20} \mathrm{Li}$ Xianting's activities may be glimpsed in English through his historical essay in V.C Doran (ed.), China's New Art post-rg8g (Hong Kong: Hanart TZ Ltd., 1993), and the essay, 'The Imprisoned Heart', Art \& Asia Pacific, I. 2 (1994).

${ }^{21}$ For an indication of his position see Nakahara Yûsuke et al, Europalia 8g: Japan in Belgium (Gent: Museum van Hedenndaagse Kunst, I989).

${ }^{22}$ Nanjô Fumio and Dana Friis-Hansen, Transculture (Tôkyô: The Japan Foundation \& Fukutake Science and Culture Foundation, 1995). Nanjô was very active in the 1980 in introducing Japanese contempoary art abroad. See, in particular, Kathy Halbreich, Kômoto Shinji, Nanjô Fumio, Thomas Sokolowski, Against Nature: Japanese art in the rg8os (New York: New York University GreyArt Gallery, 1981); Kondô Yukio, Nanjô Fumio, Peter Weiermaier, Japanische Kunst der Achziger Jahre (for the Frankfurter Kunstverein, Edition Stemmle, I99o).

${ }^{23}$ Hou Hanru was the Chinese adviser for Les Magiciens de la Terre and has since been active as a curator of modern Chinese art in Europe working from Paris. See his essays 'Departure Lounge Art', Art \& Asia Pacific, r. 2 (1994), 'Beyond the Cynical: China avantgarde in the 199os', Art \&Asia-Pacific, 3.I (i996), 'Towards an "Un-Unofficial Art": deideologicalization of China's Contemporary Art in the I9gos', Third Text, 34 (Spring I996), 'Entropy; Chinese Artists, Western Art Institutions: A new internationalism', in J. Fisher (ed.) Global Visions: Towards a new internationalism in the visual arts (London: Kala Press, 1994), 'De "décrire la réalitié" au "théâtre du monde". Lart Chinois depuis 1979'. (tr. J. Lacoste) in Harry Belleter (ed.), Face à l'Histoire (Paris: Centre Georges 
Pompidou, 1996). See also Cities on the Move, and his conversation with Gao Minglu in Inside Out.

${ }^{24}$ On 'doorkeeping' see my 'Art and its "others"-recent Australian-Asian visual exchanges', Maryanne Dever (ed.),Australia and Asia: Cultural transactions (Surrey: Curzon Press, 1997) and also Chapter Eleven of my ModernAsianArt.
${ }^{25}$ Thus catalogues like Cities on the Move, in a tendency followed by the recent catalogue Gilda Williams (ed.), Cream (London: Phaidon, I998), which declares itself to be 'a portable exhibition in a book' increasingly resemble telephone books where the artists' works become a kind of conceptual address and the name of the artist a fantastic, - unfathomable number. 